\title{
Molten metal-related ocular thermal burn: report on two cases
}

\author{
Queimadura térmica ocular por metal derretido: relato de dois casos
}

Ceyhun Arici ${ }^{1}$, Guzin Iskeleli ${ }^{1}$, Eray Atalay ${ }^{2}$, Mehmet Serhat Mangan ${ }^{3}$, Belgin Killic ${ }^{1}$

\begin{abstract}
We report two cases of severe thermal burns on the ocular surface and its adnexal appendages that developed secondary to exposure to molten heavy metal with a melting temperature of near-thousand degree Celsius. Despite aggressive intervention and strict monitoring, the profound inflammation caused significant damage to the ocular surface, ending up in an intractable infection with an unfavorable outcome. The heat of the molten metal at impact, the heat-retaining capacity of the heavy metal, the total area of the ocular surface exposed to the molten metal, and the duration of exposure determined the severity of the injury. The unfavorable outcome, despite an intensive treatment, in terms of visual acuity and cosmetic appearance, should be explicitly explained to the patient, and a psychiatrist consultation should be considered if necessary.
\end{abstract}

Keywords: Amniotic membrane/transplantation; Burns chemical; Eye burns; Metals, heavy; Eye infections, bacterial; Humans

\section{RESUMO}

Relatamos dois casos de queimaduras graves da superficie ocular e seus anexos causadas por exposição à metais pesados derretidos com temperatura de fusão de quase mil graus Celsius. Embora rigorosamente acompanhados, a inflamação intensa causou danos significativos para a superfície ocular, que acabou em uma infecção intratável com um resultado desfavorável. O calor do metal fundido no momento do impacto, a capacidade de retenção de calor do metal pesado, a área total da superfície ocular exposta ao metal fundido e a duração da exposição determinaram a gravidade da lesão que vai ocorrer. O resultado desfavorável, apesar do tratamento intensivo, em relação à acuidade visual e à aparência estética, devem ser claramente explicados ao paciente e uma consulta ao psiquiatra deve ser considerada, se necessário.

Descritores: Membrana amniótica/transplante; Queimaduras químicas; Queimaduras oculares; Metais pesados; Infecções oculares bacterianas; Acuidade visual; Humanos

\section{INTRODUCTION}

Thermal and chemical ocular burns are a medical emergency that require prompt initiation of treatment, and the usual procedures of obtaining full medical history and performing a detailed ophthalmic examination are delayed until after treatment initiation.

Thermal burns may result from contact with various materials such as steam, boiling water, fireworks explosion, and molten metal ${ }^{(1)}$. The severity of the burn varies depending on the structure of the agent, duration of contact, and contact surface area ${ }^{(2)}$. In particular, widespread destruction of limbal stem cells in severe cases, such as molten metal burns with high melting points, causes conjunctivalization of the cornea, symblepharon formation, eyelid deformities, and melting and perforation of the cornea and sclera ${ }^{(2)}$. The primary aim of the treatment is to accelerate epithelialization, to suppress inflammation, and to prevent tissue melting ${ }^{(3)}$.

Here we report the cases of two patients with severe ocular surface and eyelid burns with molten silver and bronze metal, describe the clinical follow-up, and discuss the possible poor prognostic factors.

\section{CASE REPORT}

\section{CASE 1}

A 28-year-old male was admitted to our hospital $2 \mathrm{~h}$ after having splashed molten silver metal into his right eye. On initial examination, visual acuity was limited to light perception. Anterior segment examination revealed burns of the upper and lower eyelids and eyelashes, a completely opaque cornea, $360^{\circ} \mathrm{limbal}$ ischemia, and severe burns in the bulbar conjunctiva. The fundus could not be visualized. Intraocular pressure (IOP) was $20 \mathrm{mmHg}$ as measured by Icare Pro Tonometer (Helsinki, Finland). The ocular surface was rinsed thoroughly with $1 \mathrm{~L}$ of Ringer's lactate solution over 20 min (Figure 1 A), during which a hardened silver metal, approximately $1 \mathrm{~cm}$ diameter, that was buried into the upper fornix was noticed and removed. B-scan ocular ultrasonography was also performed, which did not reveal any other intraocular damage. Medical treatment at this stage consisted of topical 10\% acetylcysteine, 10\% vitamin C, moxifloxacin, 1\% cyclopentolate, preservative-free artificial tears, 1\% prednisolone, and oral vitamin C $1.5 \mathrm{~g} /$ day. Eight hours after the injury, amniotic membrane transplantation (AMT) was performed, and a polymethylmethacrylate symblepharon ring (conformer, $24 \mathrm{~mm}$ in diameter, with a 10-mm-diameter hole in the middle) was placed in the right eye.

Visual acuity on the $20^{\text {th }}$ day after the burn was still limited to light perception. Slit-lamp examination revealed an opaque cornea, chemosis, swollen eyelids, and profound mucopurulent secretion. Samples were taken for microbiological examination (swap specimens of the bulbar conjunctiva were obtained for microbiologic analysis. Sabouraud dextrose agar was used for fungal cultures, and liquid thioglycolate medium was used for aerobic and anaerobic bacterial cultures. Gram staining for bacteria and Giemsa staining for fungi was performed for light microscopic examination). Grampositive diplococci were observed by Gram staining as were many
Funding: No specific financial support was available for this study

Disclosure of potential conflicts of interest: None of the authors have any potential conflict of interest to disclose.

Corresponding author: Ceyhun Arici. Olgunlar sokak, №: 6\10 - Bakirkoy-Istanbul 34145 - Turkey E-mail: ceyhundr@gmail.com 
yeast cells by Giemsa staining. Topical moxifloxacin was discontinued. Topical vancomycin $(50 \mathrm{mg} / \mathrm{mL})$, amphotericin B $(1.5 \mathrm{mg} / \mathrm{ml})$, $5 \%$ natamycin, and oral itraconazole (200 mg/day) were initiated. Methicillin-resistant Staphylococcus aureus (MRSA) and Candida sp. were detected by culture. One month following AMT, the residues of the amniotic membrane were removed under aseptic conditions. The conformer was removed, cleaned, and replaced. One and a half months after the ocular burn, the patient reported right ocular pain. B-scan ultrasonography was performed; however, examination of the vitreous and retina was unremarkable.

In the second month, visual acuity was light perception, and anterior segment examination revealed corneal edema, central melting, stromal infiltration, conjunctival hyperemia, chemosis, mucopurulent secretion, and eyelid edema (Figure 1 B). Despite the medical therapy, the clinical manifestations worsened; this was ascribed to increased adhesion of microorganisms and hypoxic environment due to the presence of the conformer, which was therefore removed. Repeat samples were obtained for cultures and microscopy. No bacteria were seen on Gram stain, but yeast cells were detected by Giemsa staining. The vancomycin dosage was reduced. Cultures were negative for bacteria positive for Candida sp. In the fifth month following the incident, the ocular surface infection had completely resolved. The removal of the conformer led to the inevitable consequences of severe symblepharon formation and secondary severe ocular surface damage (Figure $1 \mathrm{C}$ ).

\section{CASE 2}

A 57-year-old man had molten bronze splashed into his right eye, and was referred to our clinic 1 day after the first evaluation. On exa- mination, visual acuity was finger counting at $1 \mathrm{~m}$. Slit-lamp examination showed that the upper and lower eyelids, along with the eyelashes, were almost completely burned. The corneal epithelium was absent, and anterior segment details could not be visualized. Limbal ischemia was noted in the inferior half, and the bulbar conjunctiva was burned. Symblepharon formation was present in the inferior fornix. IOP was $19 \mathrm{mmHg}$ as measured by the iCare Pro Tonometer (Figure $2 \mathrm{~A}$ ). The ocular surface was rinsed with $1 \mathrm{~L}$ of Ringer's lactate solution for 15 min with an eyelid speculum inserted. The same day, the patient was transferred to the operating room. Adhesions in the lower fornix were removed, AMT was performed, and a conformer was inserted. Medical treatment consisted of topical 10\% acetylcysteine, $10 \%$ vitamin C, moxifloxacin, $1 \%$ cyclopentolate, preservative-free artificial tears, 1\% prednisolone, and oral vitamin C $1.5 \mathrm{~g} /$ day.

At the two-weeks follow-up visit, oral acetazolamide $250 \mathrm{mg}$ tablets were added due to IOP elevation to $28 \mathrm{mmHg}$. After one month, mucopurulent secretions, membranes on the upper and lower eyelids and palpebral conjunctiva, crusts, and amniotic membrane residues were removed under aseptic conditions after sampling for microbiological examination (Figure 2 B). The conformer was removed, cleaned, and replaced. Microscopy revealed gram-positive diplococci and yeast cells. Topical moxifloxacin was discontinued, and topical cefazolin $(50 \mathrm{mg} / \mathrm{mL})$, amphotericin B $(1.5 \mathrm{mg} / \mathrm{mL}), 5 \%$ natamycin, and oral itraconazole (200 mg/day) were initiated. $\beta$-hemolytic streptococci and Candida spp. were isolated by culture.

One and half months later, despite the polymethylmethacrylate symblepharon ring (22 $\mathrm{mm}$ diameter, with a 10-mm-diameter hole in the middle), we found adhesions between the inferior palpebral conjunctiva and inferior corneal quadrant and intense granulation
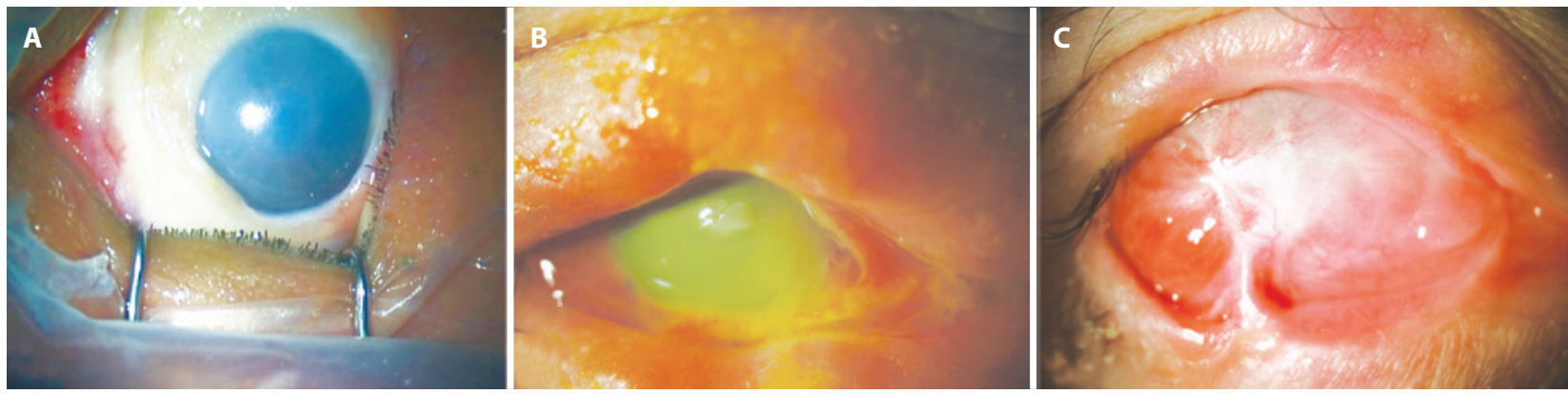

Figure 1. A) Biomicroscopic examination showed burns of the upper and lower eyelids and eyelashes, total corneal loss of transperancy, $360^{\circ}$ limbal ischemia, and diffuse burns in the bulbar conjunctiva approximately two and a half hours following an incidence of molten silver metal burn in the right eye. B) Central corneal melting, stromal infiltration, circumferential conjunctival hyperemia, chemosis, mucopurulent discharge, eyelid edema and eyelid hyperemia in the second month C) Following removal of the conformer, severe symblepharon developed, resulting in total loss of the upper and lower fornices. Total corneal conjunctivalization was seen 5 months following the incidence.
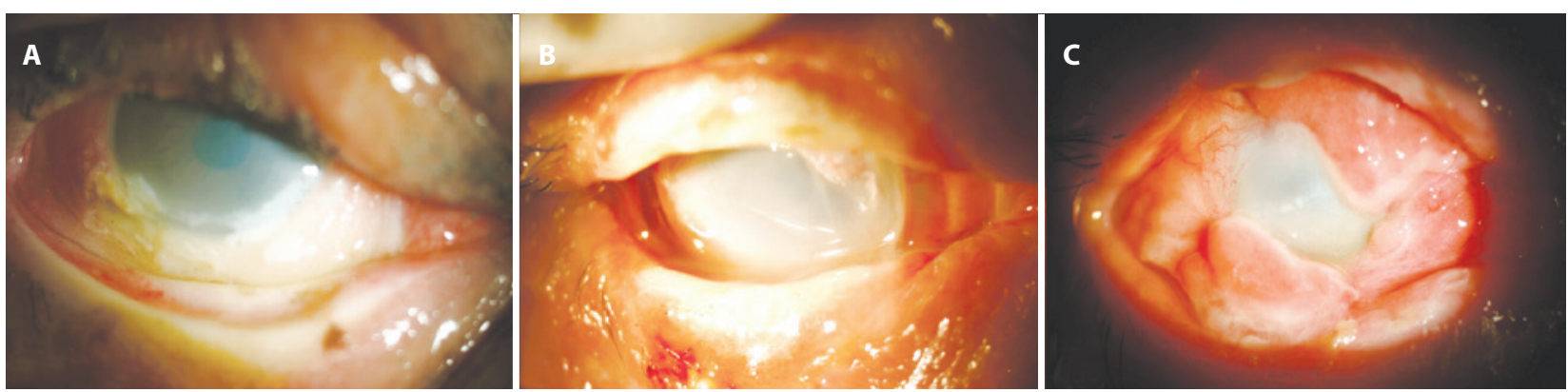

Figure 2. A) External photograph 1 day after an incidence of a molten bronze metal burn in the right eye, showing burns of the upper and lower eyelids and al eyelashes. Entire corneal epithelium was damaged. Iris and lens details were hazy. $180^{\circ}$ of the inferior limbus was ischemic and bulbar conjunctiva was burned. B) Mucopurulent secretions, membranes, crusts on the upper and lower eyelids and palpebral conjunctiva, and amniotic membrane residues on the cornea in the first month following the incidence. C) Severe hypertrophic and hyperemic conjunctiva migrated onto the opaque cornea. Symblepharon formation caused total adhesion of the superior and inferior fornix in the third month following the incidence. 
tissue in the conjunctiva; therefore, adhesions were released and granulation tissue was excised. The 22-mm diameter symblepharon ring with five 2-mm-diameter holes was re-inserted. Oral non-steroidal anti-inflammatory drug was prescribed. Despite medical therapy, infiltrates developed in the superior nasal cornea. Mucopurulent secretion developed into purulent secretion, prompting a repeat of microbiologic analyses. Bacteria were not observed on Gram stain; however, yeast cells were observed in the Giemsa staining. Cefazolin dosage was reduced from the two-hourly regimen to four times a day. Topical $(10 \mathrm{mg} / \mathrm{mL})$ and oral $(400 \mathrm{mg})$ voriconazole were added, whereas topical Natamycin 5\% and oral topical itraconazole were stopped. While cultures were negative for bacteria, Candida spp. were isolated. Due to lack of clinical improvement, the symblepharon ring was removed. The infection improved clinically over the next month, but symblepharon formation was seen in the superior and inferior fornix. Migration of hypertrophic and hyperemic conjunctiva onto the opaque cornea was observed (Figure 2 C).

\section{DISCUSSION}

Ocular thermal burns are among the most severe ocular surface injuries and may lead to limbal stem cell deficiency $y^{(1,4)}$. While mild burns heal within a few days, moderate to severe chemical and thermal burns cause ischemic necrosis of the cornea, conjunctiva, sclera, iris, and ciliary body by damaging the surface epithelium. It may also involve the eyelids and disrupt the ocular mechanical barrier. The inflammatory response that occurs due to leukocyte migration and inflammatory mediators causes scar tissue formation and perforation. The severity of tissue destruction in ocular thermal injury depends on at least four factors: temperature of the agent, heat-retaining capacity of the material, duration of contact, and area over which the heat is applied(2).

Ocular burns cause severe damage to ocular surface elements that provide protection against infections. Treatment in the acute period following an ocular surface burn should include topical antibiotics in an attempt to prevent opportunistic infections $s^{(4,5)}$. Eyelids are also damaged, the patient would require consultation with an oculoplastic surgeon if cicatricial changes ensue ${ }^{(5)}$.

Several studies have investigated the impact of high temperature on the ocular surface ${ }^{(6-8)}$. Goldblatt et al. ${ }^{(8)}$ examined the heat sensitivity of rabbit corneas with a heat conductor. Rabbit corneas were exposed to a temperature of $45^{\circ} \mathrm{C}$ for $15 \mathrm{~min}$, but no damage was observed on light microscopy. After raising the temperature to $59^{\circ} \mathrm{C}$ for $15 \mathrm{~min}$, diffuse corneal stromal edema and endothelial cell loss were observed. The first case in this report was admitted to the emergency department two hours after contact with molten sterling silver. Sterling silver is used in the jewelry and silverware industry and has a melting temperature of $893^{\circ} \mathrm{C}^{(9)}$. During ocular surface irrigation, a hardened silver metal object of approximately $1 \mathrm{~cm}$ in diameter was observed buried into the upper fornix. In this case, it is possible that the heat-related damage may have been exacerbated due to longer heat conductance. The second case was exposed to liquid commercial bronze, which is an alloy of 90\% copper and $10 \%$ zinc with a melting temperature of $1045^{\circ} \mathrm{C}^{(10)}$. In clinical practice, molten metal or glass-like agents with high melting temperatures $\left(1000^{\circ} \mathrm{C}\right)$ and significant heat-retaining capacity have been reported to cause severe burns and tissue opacification due to deep penetration in the cornea ${ }^{(11)}$.

According to the Roper Hall classification, which provides information about the extent of corneal involvement, severity of limbal ischemia, and prognosis, the first patient in this study had a stage 4 and the second had a stage 3 burn ${ }^{(12)}$. In the first case, there was $360^{\circ}$ limbal ischemia with accompanying burns in the bulbar conjunctiva, eyelids, and lashes. The second case had a relatively limited ischemia, involving $180^{\circ}$ of the inferior limbus. Disruption of the mechanical and secretory defense mechanisms of the ocular surface predisposed the patients to infections. In addition to severe sterile inflammation caused by thermal injury, a superimposed infection further increased the damage to the surface. Additionally, diffuse symblepharon developed due to severe ocular surface inflammation.

The ocular surface should be examined daily for symblepharon formation. A symblepharon ring should be inserted as soon as possible to prevent symblepharon formation. The largest size possible, allowing closure of eyelids, is preferable in order to prevent adhesions and shortening of the fornices without touching the cornea ${ }^{(4)}$.

Several studies have reported successful treatment of ocular burns using AMT with or without limbal cell transplantation ${ }^{(13-18)}$. AMT alone was reported to be efficient in terms of restoring ocular surfaces in cases of mild to moderate burns ${ }^{(14,16)}$. In cases of severe burns, AMT restored the conjunctival surface without symblepharon and reduced limbal stromal inflammation but did not prevent limbal stem cell deficiency, which required further limbal stem cell transplantation ${ }^{(16)}$. AMT was not successful in any of our two patients with similar results observed as in the study by Joseph et al.(19).

Despite aggressive treatment and close monitoring in in-patient settings, high-temperature ocular thermal burns may cause widespread damage to and severe inflammation of the ocular surface with a poor prognosis, especially in cases of superimposed infection. In these cases, appropriate expectations must be clarified and explicitly explained to the patient at the beginning, and psychiatric consultation should be sought when necessary.

\section{REFERENCES}

1. Dua HS, King AJ, Joseph A. A new classification of ocular surface burns. Br J Ophthalmol. 2001;85(11):1379-83. Comment in: Br J Ophthalmol. 2004;88(10):1353-4; author reply $1354-5$

2. Shimazaki J, Konomi K, Shimmura S, Tsubota K. Ocular surface reconstruction for thermal burns caused by fireworks. Cornea. 2006:25(2):139-45.

3. Sharifipour F, Baradaran-Rafii A, Idani E, Zamani M, Jabbarpoor Bonyadi MH. Oxygen therapy for acute ocular chemical or thermal burns: a pilot study. Am J Ophthalmol. 2011;151(5):823-8.

4. Eslani M, Baradaran-Rafii A, Movahedan A, Djalilian AR. The ocular surface chemical burns. J Ophthalmol. 2014;2014:196827.

5. Fish R, Davidson RS. Management of ocular thermal and chemical injuries, including amniotic membrane therapy. Curr Opin Ophthalmol. 2010;21(4):317-21.

6. Campbell FW, Michaelson IC. Blood-vessel formation in the cornea. Br J Ophthalmol. 1949;33(4):248-55.

7. Lister A, Greaves DP. Effect of cortisone upon the vascularization which follows corneal burns. 1. Heat burns. Br J Ophthalmol. 1951;35(11):725-9.

8. Goldblatt WS, Finger PT, Perry HD, Stroh EM, Weiser DS, Donnenfeld ED. Hyperthermic treatment of rabbit corneas. Invest Ophthalmol Vis Sci. 1989;30(8):1778-83.

9. Untracht O. Jewelry Concepts \& Technology. New York: Knopf Doubleday Publishing Group; 2011. p.393.

10. Untracht O. Jewelry Concepts \& Technology. New York: Knopf Doubleday; 2011. p.52.

11. Hamill MB. Thermal burns. In: Krachmer JH, Mannis MJ, Holland EJ, editors. Cornea $3^{\text {rd }}$ ed. Philadelphia: Elsevier Mosby; 2011. p.1178-80.

12. Roper-Hall MJ. Thermal and chemical burns. Trans Ophthalmol Soc U K. 1965;85:631-53.

13. Uçakhan $\mathrm{OO}$, Köklü G, Firat E. Nonpreserved human amniotic membrane transplantation in acute and chronic chemical eye injuries. Cornea. 2002:21(2):169-72.

14. Gomes JA, dos Santos MS, Cunha MC, Mascaro VL, Barros Jde N, de Sousa LB. Amniotic membrane transplantation for partial and total limbal stem cell deficiency secondary to chemical burn. Ophthalmology. 2003:110(3):466-73.

15. Tejwani S, Kolari RS, Sangwan VS, Rao GN. Role of amniotic membrane graft for ocular chemical and thermal injuries. Cornea. 2007;26(1):21-6.

16. Meller D, Pires RT, Mack RJ, Figueiredo F, Heiligenhaus A, Park WC, et al. Amniotic membrane transplantation for acute chemical or thermal burns. Ophthalmology. 2000; 107(5):980-9; discussion 990.

17. Sridhar MS, Bansal AK, Sangwan VS, Rao GN. Amniotic membrane transplantation in acute chemical and thermal injury. Am J Ophthalmol. 2000;130(1):134-7.

18. Shimazaki J, Yang HY, Tsubota K. Amniotic membrane transplantation for ocular surface reconstruction in patients with chemical and thermal burns. Ophthalmology. 1997;104(12):2068-76. Comment in: Ophthalmology. 2000;107(3):411-2.

19. Joseph A, Dua HS, King AJ. Failure of amniotic membrane transplantation in the treatment of acute ocular burns. Br J Ophthalmol. 2001;85(9):1065-9. Comment in: Br J Ophthalmol. 2002;86(7):831 